\title{
Dysregulation of Alzheimer's disease-related genes and proteins following cardiac arrest
}

\author{
Ryszard Pluta ${ }^{1}$, Marzena Ułamek-Kozioł ${ }^{1,2}$, Sławomir Januszewski ${ }^{1}$, Stanisław J. Czuczwar ${ }^{3}$ \\ ${ }^{1}$ Laboratory of Ischemic and Neurodegenerative Brain Research, Mossakowski Medical Research Centre, Polish Academy of Sciences, \\ Warsaw, ${ }^{2}$ First Department of Neurology, Institute of Psychiatry and Neurology, Warsaw, ${ }^{3}$ Department of Pathophysiology, Medical \\ University of Lublin, Lublin, Poland
}

\begin{abstract}
Cardiac arrest, usually occurring in the aged population, is the most important cause of high morbidity and death in developed countries. Commonly, attention, depression, cognitive impairment, spatial memory, short- and long-term memory, executive functions, decreased quality of life and social participation are disturbed following circulation arrest. Deficits in cognitive function, similar to prodromal Alzheimer's disease dementia, following cardiac arrest remain an area of concern. Recent research has focused on the post-resuscitation period to identify mechanisms of long-term brain damage and cognitive impairment. As more patients survive longer periods after cardiac arrest, attention is focused on interventions that may enhance cognitive and psychosocial perceptions. Here, we review the new data influencing the cognitive and functional outcome in the post-resuscitation period.
\end{abstract}

Key words: cardiac arrest, brain ischemia, Alzheimer's disease, genes, proteins.

\section{Introduction}

Cardiac arrest, usually encountered in the aged population, is a leading public health problem and accounts roughly for 500000 deaths per year in the USA and Europe $[1,18,20,40]$. There is a significant difference in survival rate after cardiac arrest in different places of the globe [19]. Reported survival rates reach $11 \%$ in Australia, $9 \%$ in Europe, $6 \%$ in North America and 2\% in Asia [2]. Survival from out-of-hospital cardiac arrest is < 15\% [4], while survival after in-hospital cardiac arrest is approximately $22 \%$ [7]. There is a significant risk of subsequent development of neurological injury among survivors in both groups [39]. Assessing neurological outcomes especially after post-hospital discharge is important for prognostication, but increased long-term survival of cardiac arrest patients requires efforts to improve our understanding of the full spectrum of cognitive and functional deficits observed post-arrest. These include deficits in short- and long-term memory, cognitive impairment, depression, executive dysfunction, decreased quality of life, disturbed social participation and possible progression similar to prodromal Alzheimer's disease dementia $[3,6,17,21,22,42,47-49]$. In the longer term, ischemic events following cardiac arrest may create risk factors for the development of Alzheimer's disease type 
cognitive impairment and dementia [5,12,22]. Here, we review the new data influencing the cognitive and functional outcome in the post-resuscitation period.

\section{Alzheimer's disease-related proteins after cardiac arrest}

\section{Amyloid protein precursor}

Cardiac arrest in rats leads to chronic metabolic and structural changes within special brain regions like in Alzheimer's disease: the hippocampus and temporal lobe $[10,27,34]$. Global ischemia due to cardiac arrest is the second natural pathology (including Alzheimer's disease) that causes neuronal death in the CA1 region of the hippocampus, as in Alzheimer's disease [27,33]. Brain ischemia has been found to be the most effective predictor for the later development of Alzheimer-type dementia [5,12] Post-ischemic dementia in rats might be the result of firstly the direct influence of ischemia, secondly ischemic white matter changes, and thirdly Alzheimer-type neuropathology $[5,12,31,32]$. Resuscitated rats with short-term survival up to 7 days showed strong brain staining to the $N$-terminal of amyloid protein precursor and to the $\beta$-amyloid peptide and as well as to the $C$-terminal of amyloid protein precursor $[24,25]$. Rats with very long post-resuscitation survival of 6 and 12 months demonstrated strong brain staining only for the $\beta$-amyloid peptide as well as for the $C$-terminal of amyloid protein precursor $[26,30,33]$. The staining was noted in both the intraand extracellular space. Intracellular staining was observed in damaged neurons exhibiting signs of ischemic alternations. Less often, staining for different fragments of amyloid protein precursor was found in glial cells in ischemic rat brain $[28,29]$. Extracellular different fragments of amyloid protein precursor deposits ranged from numerous widespread small dots to irregular diffuse plaques [33]. Widespread and multifocal diffuse plaques predominated in the hippocampus. In humans, different parts of amyloid protein precursor were found by immunocytochemical methods in many cortical and subcortical neurons as well as in ependymal and choroid plexus cells [51]. This staining of amyloid protein precursor was concomitant with formation of many $\beta$-amyloid peptide nonfibrillar (thioflavin-negative) plaques in the neuropil. As an effect of the changes in the blood-brain barrier permeability around many vessels, weakly $\beta$-amyloid peptide immunoreactive areas were also found [51]. The data presented provided strong evidence that the global brain ischemia due to cardiac arrest is a risk factor for amyloidosis in animals and humans. Additionally, brain ischemia induced by cardiac arrest produces a time-dependent increase in serum $\beta$-amyloid peptide level in humans [52]. The progressing generation of $\beta$-amyloid peptide has probably evolved in the pathological healing process in the ischemic brain due to cardiac arrest with subsequent alteration of blood-brain barrier vessels and huge blood-originated deposition of $\beta$-amyloid peptide as senile plaques [52].

\section{Apolipoproteins}

Strong staining for apolipoproteins A1, E and J was observed in the brain intra- and extracellular space after cardiac arrest [11,25,27]. Intracellular staining was noted in damaged neurons exhibiting signs of ischemic alternations. Less often, staining for apolipoproteins was found in glial cells in ischemic rat brain. Apolipoprotein extracellular deposits were irregular but well delineated in the brain after transient cardiac arrest $[11,25,27]$. Diffuse, broad but faintl places were also seen. Increased staining was observed in acellular, irregular, spider-like, necrotic ischemic foci, too [11]. It is of interest to note that after ischemia, deposits of apolipoproteins colocalized with deposits of different parts of amyloid protein precursor [11]. Apolipoprotein E can support the aggregation of $\beta$-amyloid peptide into the $\beta$-pleated sheet conformation. It was proposed that apolipoprotein $\mathrm{E}$ could function as a 'pathological chaperone' in the development of amyloid deposits [50]. Apolipoprotein $\mathrm{J}$ is involved in the transport of $\beta$-amyloid peptide throughout the blood-brain barrier. On the other hand, apolipoprotein J production was a result of the ischemic delayed neuronal death. The key role of apolipoproteins $A 1, E$ and $J$ in controlling the level of soluble $\beta$-amyloid peptide in the intra- and extracellular space of the brain as well as their influence on fibrillar $\beta$-amyloid peptide formation is suggested. It is also suggested that apolipoprotein $E$ and $\beta$-amyloid peptide complexes or two substances separately adhere to the neuronal remnant after its death and develop amyloid plaques. Interestingly, faint staining for apolipoprotein E, remaining in the pyramidal neuronal layer of the hippocampus, even long after its disappearance, was not- 
ed in the postischemic brain due to cardiac arrest [11] On the other hand, different parts of apolipoprotein $\mathrm{E}$ present in Alzheimer's disease brains induce the development of neurofibrillary tangle-like intracellular inclusions in neuronal cells [8]. Apolipoprotein $\mathrm{E}$ triggers $\beta$-amyloid peptide induced lysosomal leakage and apoptosis in neurons [9]. Neuronal death in Alzheimer's disease correlates with apolipoprotein $E$ uptake and intraneuronal $\beta$-amyloid peptide stabilization [15].

Apolipoproteins $\mathrm{E}$ and J can control the structure, deposition and toxicity of the $\beta$-amyloid peptide after brain ischemia due to cardiac arrest. Both lipoproteins may also be involved in $\beta$-amyloid peptide generation prior to its accumulation. These data support additive effects of both apolipoproteins on $\beta$-amyloid peptide accumulation in brain tissue and their important role in regulating extracellular $\beta$-amyloid peptide metabolism, independent of $\beta$-amyloid peptide generation $[27,36]$. Clearance of ischemic brain tissue after cardiac arrest by apolipoprotein E, as an important process for brain parenchyma repair, is suggested, too [13]. Delayed clearance may hamper healing of the blood-brain barrier after ischemic injury. The above observations support recent thinking that apolipoprotein $\mathrm{E}$ is a key protein for brain tissue remodeling after ischemic injury due to cardiac arrest. Clearance of irreversibly damaged brain parenchyma by ischemia may be one of the significant activities of apolipoprotein $E$ in the brain as a whole [13]. The above data indicate that deposition of apolipoproteins $\mathrm{E}$ and $\mathrm{J}$ after ischemic brain injury may represent a secondary injury factor that could exacerbate healing of the ischemic brain as a whole. Accumulation of extracellular apolipoproteins $E$ and J was observed after ischemic neuronal death $[11,27]$.

\section{Expression of Alzheimer's disease risk genes after cardiac arrest}

In the rat selectively vulnerable CA1 area of the hippocampus, the expression of amyloid protein precursor gene decreased below the basal value 2 days after ischemic injury. Seven and 30 days after brain ischemia due to cardiac arrest, expression of the amyloid protein precursor gene increased by about $80 \%$ at both times compared to the basal value [14]. In the medial temporal lobe cortex, expression of the amyloid protein precursor gene was reduced below the basal value 2 days following ischemic brain injury. But 7 and 30 days following ischemia, the amyloid protein precursor gene expression was increased in the temporal lobe by about $100 \%$ above the basal value at both times [38].

$\beta$-secretase gene expression increased by about $400 \%$ maximally after brain ischemia due to cardiac arrest in the rat CA1 area of the hippocampus with 2 -day survival. Seven days after ischemia, $\beta$-secretase expression increased by $100 \%$. But 30 days after brain ischemia, $\beta$-secretase gene expression decreased below the basal value [14]. $\beta$-secretase gene expression rose to a maximum of $400 \%$ in the medial temporal lobe cortex 2 days after ischemic brain injury. Seven and 30 days after temporal lobe ischemia, $\beta$-secretase gene expression was diminished below the basal value [38].

In the rat selectively vulnerable CA1 subfield of hippocampus, presenilin 1 gene expression increased by about $200 \%$ but presenilin 2 increased by more than $300 \% 2$ days after brain ischemia due to cardiac arrest [14]. Seven days after brain ischemia, presenilin 1 and 2 gene expression increased by $90 \%$ and $70 \%$, respectively. But 30 days after the ischemic injury, presenilin 1 and 2 gene expression decreased below the basal value [14]. In the medial temporal lobe cortex, presenilin 1 gene expression decreased below and presenilin 2 increased above the basal level by $180 \% 2$ days after brain ischemia. Seven days of survival following brain ischemia due to cardiac arrest, presenilin 1 gene expression was diminished below but presenilin 2 was elevated above the basal value by $50 \%$. Presenilin 1 gene expression increased above the basal level by $40 \%$ but expression of presenilin 2 was reduced below the basal value 30 days after a brain ischemic episode [37].

It was found that the autophagy gene in the hippocampus CA1 area was not significantly modified 2, 7 and 30 days after brain ischemia due to cardiac arrest. But the mitophagy gene was significantly upregulated at day 2 (by about 100\%) and decreased below the basal values at days 7 and 30 [46]. The gene expression of caspase 3 in the hippocampus CA1 area 2 days after ischemic brain injury increased by more than $300 \%$ compared to the basal level. But 7 days after ischemia, due to cardiac arrest, its expression was close to the basal value. Thirty days after brain ischemic injury, in the above area the gene expression was reduced below the basal value [46]. 
In the medial temporal lobe cortex, expression of the autophagy gene increased by $100 \%$ above the basal value 2 days after a brain ischemia episode in rats [44]. Seven- and 30-day expression of the autophagy gene was reduced to $60 \%$ and $50 \%$ compared to the basal value, respectively [44]. In the medial temporal lobe cortex, the mitophagy gene decreased by about $200 \%$ below the basal level 2 days following brain ischemic injury. Seven and 30 days after ischemic episode, expression of the mitophagy 3 gene increased by about $400 \%$ and $50 \%$, respectively. In the medial temporal lobe cortex, the apoptotic gene caspase 3 was reduced below its basal value 2 days after brain ischemia due to cardiac arrest. Seven and 30 days after ischemic episode, expression of the caspase 3 gene increased by $50 \%$ above its basal value at both times [44].

Brain ischemia due to cardiac arrest has shed new light on brain vascular system dysfunction as a key contributor to dementia and chronic neurodegenerative factor in the development of Alzheimer's disease. Current knowledge regarding the induction of Alzheimer's disease-related genes and proteins as well as neuropathology of both brain ischemia and Alzheimer's disease indicate that similar mechanisms contribute to neuronal cell death and brain tissue neurodegradation and finally dementia $[35,36,43,45]$. Alzheimer's disease-related proteins can contribute to and precipitate post-ischemic brain neurodegeneration with the development of Alzheimer's disease type dementia [5,12]. Over time, some brain structures, such as the hippocampus, would become permanently at risk of repeated ischemia, leading to fatigue and the neuropathological alterations of Alzheimer's disease-type. Nevertheless, the ischemically altered brain as a whole can predispose to progressive neuronal cell dysfunction and death, elicitation of Alzheimer's disease-related genes and proteins, and finally can lead to chronic and progressive neuropathology, including the development of Alzheimer's disease dementia $[35,36,43,45]$. Cardiac arrest-induced dysregulation of Alzheimer's disease-related genes and proteins may play a key role in late onset of Alzheimer's disease-type dementia $[14,37,38,43-46]$.

\section{Conclusions}

The experience of cardiac arrest and its consequences is overwhelming for patients' families and their doctors performing treatment. Patients after cardiac arrest have a significant risk of death and progressing development of disability $[1,18,40]$. Cardiac arrest, always associated with global brain injury in the short-term period, is characterized by early ischemic encephalopathy leading to severe neurological deficits. In the long term, the post-resuscitation cognitive impairment has an amnestic feature, characterized by greater memory impairment than executive dysfunction, similar to prodromal Alzheimer's disease dementia $[5,11,22]$. This association with prodromal Alzheimer's disease dementia is supported by genomic and proteomic observations noted in basic science investigations of brains after cardiac arrest, including the increased level of $\beta$-amyloid peptide and number of receptors for advanced glycation end products transporting amyloid throughout the blood-brain barrier to the brain tissue as well as different structures of brain dysregulated expression of genes such as amyloid protein precursor, $\beta$-secretase, presenilin 1 and 2, autophagy, mitophagy and caspase $3[11,14,16,24,27,33,37,38,43-46,51]$. Recent studies apart from earlier hippocampus changes [23] have shown a more diffuse pattern of brain injury as a whole, which is supported by imaging and neuropathological data with severe brain atrophy and cognitive impairment following cardiac arrest $[5,12,27,41]$.

The investigation of long-term cognitive impairment in humans associated with cardiac arrest has been limited by the follow-up duration and heterogeneity of study outcome measures $[3,6,21,48]$. Cognitive impairment after cardiac arrest is multifactorial in nature. It is not only influenced by the initial ischemic episode, but also by comorbidities prevalent in cardiac arrest patients and factors connected with hospital interventions. The influence of cardiac arrest on cognitive and functional outcomes warrants further study, given the high prevalence of prodromal Alzheimer's disease dementia in cardiac arrest survivors [22]. Future studies on final mechanisms of cognitive deficits can improve quality of life to overall well being for cardiac arrest patients. Thus, it is very likely that there is a link between cardiac arrest and the global brain ischemia-induced expression of Alzheimer's disease risk genes discussed in this review. Understanding the mechanisms underlying the association of these genes with high risk for Alzheimer's disease will provide the most meaningful targets for therapeutic development to date. 


\section{Disclosure}

\section{Authors report no conflict of interest.}

\section{References}

1. Atwood C, Eisenberg MS, Herlitz J, Rea TD. Incidence of EMStreated out-of-hospital cardiac arrest in Europe. Resuscitation 2005; 67: 75-80.

2. Berdowski J, Berg RA, Tijssen JG, Koster RW. Global incidences of out-of-hospital cardiac arrest and survival rates: systematic review of 67 prospective studies. Resuscitation 2010; 81: 14791487.

3. Buanes EA, Gramstad A, Sovig KK, Hufthammer KO, Flaatten H, Husby T, Langørgen J, Heltne JK. Cognitive function and health-related quality of life four years after cardiac arrest. Resuscitation 2015; 89: 13-18.

4. Chan PS, McNally B, Tang F, Kellermann A, CARES Surveillance Group. Recent trends in survival from out-of-hospital cardiac arrest in the United States. Circulation 2014; 130: 1876-1882.

5. Cohan CH, Neumann JT, Dave KR, Alekseyenko A, Binkert M, Stransky K, Lin HW, Barnes CA, Wright CB, Perez-Pinzon MA. Effect of cardiac arrest on cognitive impairment and hippocampal plasticity in middle-aged rats. PLoS One 2015; 10: e0124918.

6. Cronberg T, Lilja G, Rundgren M, Friberg $H$, Widner $H$. Longterm neurological outcome after cardiac arrest and therapeutic hypothermia. Resuscitation 2009; 80: 1119-1123.

7. Girotra S, Nallamothu BK, Spertus JA, Li Y, Krumholz HM, Chan PS; American Heart Association Get with the Guidelines - Resuscitation Investigators. Trends in survival after in-hospital cardiac arrest. N Engl J Med 2012; 367: 1912-1920.

8. Huang Y, Liu XQ, Wyss-Coray T, Brecht WJ, Sanan DA, Mahley RW. Apolipoprotein E fragments present in Alzheimer's disease brains induce neurofibrillary tangle-like intracellular inclusions in neurons. Proc Natl Acad Sci USA 2001; 98: 88388843.

9. Ji ZS, Miranda RD, Newhouse YM, Weisgraber KH, Huang Y, Mahley RW. Apolipoprotein E4 potentates amyloid $\beta$ peptide-induced lysosomal leakage and apoptosis in neuronal cells. J Biol Chem 2002; 277: 21821-21828.

10. Jabłoński M, Maciejewski R, Januszewski S, Ułamek M, Pluta R. One year follow up in ischemic brain injury and the role of Alzheimer factors. Physiol Res 2011; 60 (Suppl 1): S113-S119.

11. Kida E, Pluta R, Lossinsky AS, Gołąbek A, Choi-Miura NH, Wiśniewski H, Mossakowski MJ. Complete cerebral ischemia with shortterm survival in rat induced by cardiac arrest. II. Extracellular and intracellular accumulation of apolipoproteins $E$ and J in the brain. Brain Res 1995; 674: 341-346.

12. Kiryk A, Pluta R, Figiel I, Mikosz M, Ułamek M, Niewiadomska G, Jabłoński M, Kaczmarek L. Transient brain ischemia due to cardiac arrest causes irreversible long-lasting cognitive injury. Behav Brain Res 2011; 219: 1-7.

13. Kitagawa K, Matsumoto M, Kuwabara K, Ohtsuki T, Hori M. Delayed, but marked, expression of apolipoprotein $E$ is involved in tissue clearance after cerebral infarction. J Cereb Blood Flow Metab 2001; 21: 1199-1207.
14. Kocki J, Ułamek-Kozioł M, Bogucka-Kocka A, Januszewski S, Jabłoński M, Gil-Kulik P, Brzozowska J, Petniak A, FurmagaJabłońska W, Bogucki J, Czuczwar SJ, Pluta R. Dysregulation of amyloid precursor protein, $\beta$-secretase, presenilin 1 and 2 genes in the rat selectively vulnerable CA1 subfield of hippocampus following transient global brain ischemia. J Alzheimers Dis 2015; 47: 1047-1056.

15. LaFerla FM, Troncoso JC, Strickland DK, Kawas CH, Jay G. Neuronal cell death in Alzheimer's disease correlates with apoE uptake and intracellular A $\beta$ stabilization. J Clin Invest 1997; 100: 310-320.

16. Maślińska D, Laure-Kamionowska M, Taraszewska A, Deręgowski K, Maśliński S. Immunodistribution of amyloid beta protein (A $\beta$ ) and advanced glycation end-product receptors (RAGE) in choroid plexus and ependyma of resuscitated patients. Folia Neuropathol 2011; 49: 295-300.

17. Moualert VR, Verbundt JA, van Heugten CM, Wade DT. Cognitive impairments in survivors of out-of-hospital cardiac arrest: a systematic review. Resuscitation 2009; 80: 297-305.

18. Mozaffarian D, Benjamin EJ, Go AS, Arnett DK, Blaha MJ, Cushman M, de Ferranti S, Després JP, Fullerton HJ, Howard VJ, Huffman MD, Judd SE, Kissela BM, Lackland DT, Lichtman JH, Lisabeth LD, Liu S, Mackey RH, Matchar DB, McGuire DK, Mohler ER $3^{\text {rd }}$, Moy CS, Muntner P, Mussolino ME, Nasir K, Neumar RW, Nichol G, Palaniappan L, Pandey DK, Reeves MJ, Rodriguez CJ, Sorlie PD, Stein J, Towfighi A, Turan TN, Virani SS, Willey JZ, Woo D, Yeh RW, Turner MB; American Heart Association Statistics Committee and Stroke Statistics Subcommittee. Heart disease and stroke statistics - 2015 update: a report from the American Heart Association. Circulation 2015; 131: e29-322.

19. Mozaffarian D, Benjamin EJ, Go AS, Arnett DK, Blaha MJ, Cushman M, Das SR, de Ferranti S, Després JP, Fullerton HJ, Howard VJ, Huffman MD, Isasi CR, Jiménez MC, Judd SE, Kissela BM, Lichtman JH, Lisabeth LD, Liu S, Mackey RH, Magid DJ, McGuire DK, Mohler ER 3rd, Moy CS, Muntner P, Mussolino ME, Nasir K, Neumar RW, Nichol G, Palaniappan L, Pandey DK, Reeves MJ, Rodriguez CJ, Rosamond W, Sorlie PD, Stein J, Towfighi A, Turan TN, Virani SS, Woo D, Yeh RW, Turner MB; American Heart Association Statistics Committee; Stroke Statistics Subcommittee. Executive summary: heart disease and stroke statistics - 2016 update: a report from the American Heart Association. Circulation 2016; 133: 447-454.

20. Nichol G, Thomas E, Callaway CW, Hedges J, Powell JL, Aufderheide TP, Rea T, Lowe R, Brown T, Dreyer J, Davis D, Idris A, Stiell I; Resuscitation Outcomes Consortium Investigators. Regional variation in out-of-hospital cardiac arrest incidence and outcome. JAMA 2008; 300: 1423-1431.

21. Nunes B, Pais J, Garcia R, Magalhaes Z, Granja C, Silva MC. Cardiac arrest: long term cognitive and imaging analysis. Resuscitation 2003; 57: 287-297.

22. Perez CA, Samudra N, Aiyagari V. Cognitive and functional consequence of cardiac arrest. Curr Neurol Neurosci Rep 2016; 16: 70.

23. Petito CK, Feldmann E, Pulsinelli WA, Plum F. Delayed hippocampal damage in humans following cardiorespiratory arrest. Neurology 1987; 37: 1281-1286.

24. Pluta R, Kida E, Lossinsky AS, Gołąbek AA, Mossakowski MJ, Wiśniewski HM. Complete cerebral ischemia with shortterm 
survival in rats induced by cardiac arrest. I. Extracellular accumulation of Alzheimer's $\beta$ amyloid protein precursor in the brain. Brain Res 1994; 649: 323-328.

25. Pluta R, Barcikowska M, Dębicki G, Ryba M, Januszewski S Changes in amyloid precursor protein and apolipoprotein $E$ immunoreactivity following ischemic brain injury in rat with long-term survival: influence of idebenone treatment. Neurosci Lett 1997; 232: 95-98.

26. Pluta R, Barcikowska M, Mossakowski MJ, Zelman I. Cerebral accumulation of beta-amyloid following ischemic brain injury with long-term survival. Acta Neurochir (Suppl) 1998; 71: 206-208.

27. Pluta $R$. The role of apolipoprotein $E$ in the deposition of $\beta$-amy loid peptide during ischemia-reperfusion brain injury. A model of early Alzheimer's disease. Ann NY Acad Sci 2000; 903: 324-334.

28. Pluta R. Glial expression of the beta-amyloid peptide in cardiac arrest. J Neurol Sci 2002; 203-204: 277-280.

29. Pluta R. Astroglial expression of the beta-amyloid in ischemiareperfusion brain injury. Ann N Y Acad Sci 2002; 977: 102-108.

30. Pluta R. Blood-brain barrier dysfunction and amyloid precursor protein accumulation in microvascular compartment following ischemia-reperfusion brain injury with 1-year survival. Acta Neurochir (Suppl) 2003; 86: 117-122.

31. Pluta R, Ułamek M, Januszewski S. Micro-blood-brain barrier openings and cytotoxic fragments of amyloid precursor protein accumulation in white matter after ischemic brain injury in long-lived rats. Acta Neurochir (Suppl) 2006; 96: 267-271.

32. Pluta R, Januszewski S, Ułamek M. Ischemic blood-brain barrier and amyloid in white matter as etiological factors in leukoaraiosis. Acta Neurochir (Suppl) 2008; 102: 353-356.

33. Pluta R, Ułamek M, Jabłoński M. Alzheimer's mechanisms in ischemic brain degeneration. Anat Rec 2009; 292: 1863-1881.

34. Pluta R, Januszewski S, Jabłoński M, Ułamek M. Factors in creepy delayed neuronal death in hippocampus following brain ischemia-reperfusion injury with long-term survival. Acta Neurochir (Suppl) 2010; 106: 37-41.

35. Pluta R, Furmaga-Jabłońska W, Maciejewski R, Ułamek-Kozioł M Jabłoński $M$. Brain ischemia activates $\beta$ - and $\gamma$-secretase cleavage of amyloid precursor protein: Significance in sporadic Alzheimer's Disease. Mol Neurobiol 2013; 47: 425-434.

36. Pluta R, Jabłoński M, Ułamek-Kozioł M, Kocki J, Brzozowska J, Januszewski S, Furmaga-Jabłońska W, Bogucka-Kocka A, Maciejewski R, Czuczwar SJ. Sporadic Alzheimer's disease begins as episodes of brain ischemia and ischemically dysregulated Alz heimer's disease genes. Mol Neurobiol 2013; 48: 500-515.

37. Pluta R, Kocki J, Ułamek-Kozioł M, Bogucka-Kocka A, Gil-Kulik P, Januszewski S, Jabłoński M, Petniak A, Brzozowska J, Bogucki J, Furmaga-Jabłońska W, Czuczwar SJ. Alzheimer-associated presenilin 2 gene is dysregulated in rat medial temporal lobe cortex after complete brain ischemia due to cardiac arrest. Pharmacol Rep 2016; 68: 155-161.

38. Pluta R, Kocki J, Ułamek-Kozioł M, Petniak A, Gil-Kulik P, Januszewski S, Bogucki J, Jabłoński M, Brzozowska J, Furmaga-Jabłońska W, Bogucka-Kocka A, Czuczwar SJ. Discrepancy in expression of $\beta$-secretase and amyloid- $\beta$ protein precursor in Alzheimer-related genes in the rat medial temporal lobe cortex following transient global brain ischemia. J Alzheimers Dis 2016; 51: 1023-1031.
39. Samaniego EA, Persoon S, Wijman CA. Prognosis after cardiac arrest and hypothermia: a new paradigm. Curr Neurol Neurosci Rep 2011; 11: 111-119.

40. Sans S, Kesteloot H, Kromhout D. The burden of cardiovascular diseases mortality in Europe. Task Force of the European Society of Cardiology on Cardiovascular Mortality and Morbidity Statistics in Europe. Eur Heart J 1997; 18: 1231-1248.

41. Sekeljic V, Bataveljic D, Stamenkovic S, Ułamek M, Jabłoński M, Radenovic L, Pluta R, Andjus PR. Cellular markers of neuroinflammation and neurogenesis after ischemic brain injury in the long-term survival rat model. Brain Struct Funct 2012; 217: 411-420.

42. Sulzgruber P, Kliegel A, Wandaller C, Uray T, Losert H, Laggner AN, Sterz F, Kliegel M. Survivors of cardiac arrest with good neurological outcome show considerable impairments of memory functioning. Resuscitation 2015; 88: 120-125.

43. Ułamek-Kozioł M, Pluta R, Bogucka-Kocka A, Januszewski S, Kocki J, Czuczwar SJ. Brain ischemia with Alzheimer phenotype dysregulates Alzheimer's disease-related proteins. Pharmacol Rep 2016; 68: 582-591.

44. Ułamek-Kozioł M, Kocki J, Bogucka-Kocka A, Petniak A, GilKulik P, Januszewski S, Bogucki J, Jabłoński M, Furmaga-Jabłońska W, Brzozowska J, Czuczwar SJ, Pluta R. Dysregulation of autophagy, mitophagy and apoptotic genes in the medial temporal lobe cortex in an ischemic model of Alzheimer's disease. J Alzheimers Dis 2016; 54: 113-121.

45. Ułamek-Kozioł M, Pluta R, Januszewski S, Kocki J, BoguckaKocka A, Czuczwar SJ. Expression of Alzheimer's disease risk genes in ischemic brain degeneration. Pharmacol Rep 2016; 68: 1345-1349.

46. Ułamek-Kozioł M, Kocki J, Bogucka-Kocka A, Januszewski S, Bogucki J, Czuczwar SJ, Pluta R. Autophagy, mitophagy and apoptotic gene changes in the hippocampal CA1 area in a rat ischemic model of Alzheimer's disease. Pharmacol Rep 2017; 69: 1289-1294.

47. van Alem AP, de Vos R, Schmand B, Koster RW. Cognitive impairment in survivors of out-of-hospital cardiac arrest. Am Heart J 2004; 148: 416-421.

48. Wachelder EM, Moulaert VR, van Heugten C, Verbunt JA, Bekkers SC, Wade DT. Life after survival: long-term daily functioning and quality of life after an out-of-hospital cardiac arrest. Resuscitation 2009; 80: 517-522.

49. Wilson BA. Cognitive functioning of adult survivors of cerebral hypoxia. Brain Inj 1996; 10: 863-874.

50. Wisniewski T, Frangione B. Apolipoprotein E: a pathological chaperone protein in patients with cerebral and systemic amyloid. Neurosci Lett 1992; 135: 235-238.

51. Wiśniewski HM, Maslińska D. Beta-protein immunoreactivity in the human brain after cardiac arrest. Folia Neuropathol 1996; 34: 65-71.

52. Zetterberg H, Mörtberg E, Song L, Chang L, Provuncher GK, Patel PP, Ferrell E, Fournier DR, Kan CW, Campbell TG, Meyer R, Rivnak AJ, Pink BA, Minnehan KA, Piech T, Rissin DM, Duffy DC, Rubertsson S, Wilson DH, Blennow K. Hypoxia due to cardiac arrest induces a time-dependent increase in serum amyloid $\beta$ levels in humans. PLoS One 2011; 6: e28263. 